\title{
HUMORAL IMMUNE RESPONSES AGAINST MEMBERS OF THE HSP70 FAMILY IN TOXOPLASMA GONDII
}

\author{
KATSUYUKI YUI ${ }^{1}$ AND AKIHIKo YANO ${ }^{2}$ \\ Received May 11, 1998/Accepted September 21, 1998
}

\begin{abstract}
The cDNA for a member of stress induced $70-\mathrm{kDa}$ protein family (hsp70) from Toxoplasma gondii was cloned. The deduced amino acid sequence revealed a 667 amino acid protein $70-80 \%$ homologous to other parasite and mammalian hsp70s. Southern blot analysis suggested that it is encoded by an intronless gene. A protein of $\sim 77-\mathrm{kDa}$ was identified in a lysate of $T$. gondii tachyzoites by mAbs generated against the recombinant hsp70 protein. Anti-human hsp70 mAb also cross-reacted with a $T$. gondii protein of the identical molecular weight. However, immunoprecipitation and Western blot analysis of these proteins indicated that it was distinct from the cloned hsp70 product, suggesting that $T$. gondii expresses another hsp70-like protein. Among 22 mice infected with a low virulence Fukaya strain of $T$. gondii, 6 mice exhibited significant humoral anti-hsp70 Ab responses. This Ab responses peaked at 1-2 weeks of infection, plateaued for 2-3 weeks and gradually declined to nearly undetectable levels at 6 weeks of infection. In contrast, the levels of serum $\mathrm{Ab}$ specific for soluble tachyzoite Ags continued to increase during the infection in all mice examined. These features suggest that pathogen-derived hsp70 may play a unique role in the induction and maintenance of the host immune responses.
\end{abstract}

Key words: hsp70, Toxoplasma gondii, immune responses, antibody

\section{INTRODUCTION}

Members of the stress induced $70-\mathrm{kDa}$ protein family, heat shock protein 70 (hsp70), are expressed in every cell type of eukaryotic as well as prokaryotic cells. They carry out essential functions as molecular chaperones in protein folding, translocation and multimeric polypeptide assembly (reviewed in Gething and Sambrook, 1992; Hartl, 1996; Melnick and Argon, 1995). Each eukaryotic cell expresses several different proteins of the hsp70 family localized in different cellular compartments including the constitutively expressed heat shock cognate protein 70 (hsc70) and stress induced hsp70 in the cytosol, glucose-regulated protein 78 (grp78) in the lumen of the endoplasmic reticulum, and grp75 in the mitochondrial matrix. Consistent with their essential functions, the amino acid sequence of hsp70 is highly homologous among different species. However, hsp70s are immunodominant antigens of many infectious microorganisms. Antibodies against hsp70s have been described in the serum of patients with a variety of pathogens including Plasmodium falciparum (Yang et al., 1987), Leishmania donovani (MacFarlane et al., 1990), Trypanosoma cruzi (Engman et al., 1990), Schistosoma mansoni (Hedstrom et al., 1987), and Mycobacterium (Young et al., 1985). T cells from previously infected individuals have been reported to proliferate in response to native Mycobacterium bovis hsp70 (Young and Mehara, 1985) as well as recombinant hsp70 (McKenzie et al., 1991). Those studies indicate that hsp70s are potent antigens for both $\mathrm{B}$ and $\mathrm{T}$ cells during infection with these pathogens. T. gondii is an obligate intracellular protozoan parasite which can infect a number of different cell types (Frenkel, 1988; McCabe and Remington, 1988). Infection of healthy individuals with the parasite induces specific antibody production and both class I and class II restricted T cell responses, culminating in powerful protective immunity (Aosai et al., 1994; Yang et al., 1995; Yano et al., 1989). However, the exposed individuals remain chronically infected without apparent symptoms; and the outcome can be fatal if the host's immune system becomes com-

1 Department of Medical Zoology, Nagasaki University School of Medicine

2 Department of Parasitology, Chiba University School of Medicine Correspondence; Akihiko Yano, Department of Parasitology, Chiba University School of Medicine, 1-8-1 Inohana, Chuo-ku, Chiba 260-8679, Japan 
promised. Considering the importance of the pathogenderived hsp70 in the induction of immune responses against intracellular organisms, we have cloned a cDNA homologous to hsp70 from a $T$. gondii cDNA library. A panel of mAbs was generated against the recombinant hsp70 protein. The humoral immune response against this hsp70 was investigated in mice infected with a low virulence Fukaya strain of $T$. gondii. The kinetics of the antibody response against hsp70 was distinct from that against other soluble $T$. gondii antigens, suggesting a unique role of pathogen derived hsp70 in triggering and maintaining the host immune response.

\section{MATERIALS AND METHODS}

T. gondii and animals:

Tachyzoites of the $T$. gondii $\mathrm{RH}$ strain were maintained in vitro using the human B cell line ARH. The Fukaya strain was maintained in vivo by repeated oral passages of brain cysts containing bradyzoites into B10.A (4R) mice. BALB/c and $\mathrm{C} 57 \mathrm{BL} / 6$ (B6) mice were originally purchased from SRC (Shizuoka) and were maintained in the animal facility of Nagasaki University. B10.A(4R) mice have been maintained in our laboratory for sometime.

\section{Isolation of $T$. gondii hsp70 cDNA:}

A MOSElox cDNA library was constructed from poly (A) ${ }^{+}$RNA isolated from tachyzoites of the $T$. gondii $\mathrm{RH}$ strain using a cDNA synthesis module and a cDNA rapid cloning module (Amersham, Buckinghamshire, England) according to the manufacturer's instructions. The library was screened with the radiolabelled human hsp70 DNA probe (ATCC, Rockville, MD) (Hunt and Morimoto, 1985) in $3 \times \mathrm{SSC}, 5 \times$ Denhardt's solution, $50 \mathrm{mM}$ Tris Base (pH 7.5), 1 mM EDTA, 0.5\% SDS and $20 \mu \mathrm{g} / \mathrm{m} l$ denatured salmon sperm DNA at $60^{\circ} \mathrm{C}$, and washed in $0.1 \times \mathrm{SSC}$ and $0.1 \% \mathrm{SDS}$ at $60^{\circ} \mathrm{C}$. From a total of $1 \times 10^{5}$ cDNA clones, 15 clones specifically hybridizing with human hsp70 cDNA were selected. The longest cDNA, pTH14, was subcloned into Bam HI digested pBluescript SKII (+) (Stratagene, La Jolla, CA, U.S.A.), and subjected to DNA sequencing using a Taq DyeDeoxy Terminator Cycle Sequencing kit (Applied Biosystems, Foster City, CA, U.S.A.). Analysis of the nucleotide and amino acid sequences was performed using Genetyx-Mac software (Software Development Co., Tokyo).

Southern and Northern blot analysis:

Southern and Northern blottings were performed as described previously (Komori et al., 1993). DNA extracted from tachyzoites of the $T$. gondii $\mathrm{RH}$ strain was digested with restriction enzymes, separated on a $1 \%$ agarose gel, and transferred to a nylon membrane. A Pst I-Kpn I fragment (nucleotides 430-935) and a Pvull-Hind III fragment (nucleotides 1668-2123) of $T$. gondii hsp70 cDNA were used as probes for the $5^{\prime}$ and $3^{\prime}$ regions, respectively, of the gene. The blot was prehybridized and hybridized with ${ }^{32} \mathrm{P}$-labeled probe in $5 \times$ SSC, $5 \times$ Denhardt's solution, $50 \mathrm{mM}$ Tris ( $\mathrm{pH} 7.5$ ), 1\% SDS and $50 \mu \mathrm{g} / \mathrm{m} l$ salmon sperm DNA for $16 \mathrm{hr}$ at $65^{\circ} \mathrm{C}$. The filter was washed twice in $2 \times \mathrm{SSC} / 0.1 \% \mathrm{SDS}$ at $20^{\circ} \mathrm{C}$, twice in $0.2 \times \mathrm{SSC} / 0.1 \% \mathrm{SDS}$ at $20^{\circ} \mathrm{C}$, and twice in $0.1 \% \mathrm{SSC} / 0.1 \% \mathrm{SDS}$ at $65^{\circ} \mathrm{C}$. After being rinsed with $2 \times \mathrm{SSC}$, the washed blot was analyzed using a bioimage analyzer, BAS5000Mac (Fujifilm, Tokyo).

RNA was extracted from the RH strain of $T$. gondii by the method described (Chomczynski and Sacchi, 1987), denatured with formaldehyde, subjected to electrophoresis through a $1 \%$ agarose gel and transferred to a nylon membrane. The blot was hybridized and analyzed by the method described for Southern blotting.

Expression and purification of the recombinant hsp70 proteins:

The Xho I site was introduced into the $5^{\prime}$ region of the full length $T$. gondii hsp70 cDNA (pTH14) and the ATG start codon was removed by PCR with the oligonucleotide primers $\mathrm{TH}^{\prime}$ (5'-catctcgaggcggactctcctgctgt$3^{\prime}$ ) and T7 using pTH14 subcloned into pBluescript IISK as a template. The PCR product was digested with Xho $\mathrm{I}$ and Bam HI and subcloned into the pET15b expression vector (Novagen, Madison, WI, U.S.A.). This plasmid allows the $\mathrm{N}$-terminal fusion of a histidine tag sequence to the T. gondii hsp70 protein. N-terminal and C-terminal fragments of hsp70 were also expressed as fusion proteins using pET15b. These constructs were generated by PCR using pTH14 as a template with $\mathrm{TH}^{\prime}$ plus $5^{\prime}$-cgggatccttaaccgagagagagaggcgc- $3^{\prime}$ primers, and $5^{\prime}$ catctcgagctggagacagctggtggt $-3^{\prime}$ plus T7 primers, respectively. After digestion with Xho I and Bam HI, each PCR product was subcloned into the pET15b expression vector.

A Bam HI-Hind III digested fragment of the genomic human hsp70 gene (Hunt and Morimoto, 1985) was subcloned into pBluescript SK II. The gene was amplified by PCR using $\mathrm{pH} 1$ primer $\left(5^{\prime}\right.$-catctcgaggccaaagccgcggcag-3') and T7 primer. The PCR product was digested with Xho I (located within the $\mathrm{pH} 1$ primer) and Hind III (located within the multiple clon- 
ing site of pBluescript SK II) and was subcloned into pGEM7Zf $(+)$ (Promega, Madison, WI, U.S.A.). The DNA fragment containing the hsp70 gene was isolated by digesting this plasmid with Xho I and Bam HI and subcloned into pET15b. The resulting construct can express human hsp70 protein containing the $\mathrm{N}$-terminal fusion of a histidine tag sequence.

Escherichia coli BL21 (DE3) cells harboring the expression plasmid $\mathrm{pET} 15 \mathrm{~b}$ construct were cultured at $37^{\circ} \mathrm{C}$ in LB medium supplemented with ampicillin. Expression was induced by the addition of IPTG at a final concentration of $1 \mathrm{mM}$, and the cells were cultured for an additional $3 \mathrm{hr}$. The cells were then suspended in $5 \mathrm{mM}$ imidazole, $0.5 \mathrm{M} \mathrm{NaCl}$ and $20 \mathrm{mM}$ Tris (pH8.0) and lysed by sonication. The lysate was cleared by centrifugation, and histidine tagged recombinant protein was purified from the supernatant using a ProBond column (Invitrogen, San Diego, CA, U.S.A.) following standard procedures. Briefly, cells were homogenized in binding buffer ( $5 \mathrm{mM}$ imidazole, $0.5 \mathrm{M} \mathrm{NaCl}, 20 \mathrm{mM}$ Tris- $\mathrm{HCl}, \mathrm{pH}$ 8.0). After centrifugation, the supernatant was applied to the ProBond column. The column was washed with binding buffer followed by wash buffer (60 mM imidazole, $0.5 \mathrm{M} \mathrm{NaCl}, 20 \mathrm{mM}$ Tris- $\mathrm{HCl} \mathrm{pH}$ $8.0)$. The bound protein was eluted with elution buffer (1 M imidazole, $0.5 \mathrm{M} \mathrm{NaCl}, 20 \mathrm{mM}$ Tris- $\mathrm{HCl}, \mathrm{pH} 8.0$ ) and was dialyzed extensively against PBS. SDS-PAGE analysis of the purified tagged proteins from full length, $\mathrm{N}$-terminal and C-terminal $T$. gondii hsp70 constructs indicated single major bands of $76-\mathrm{kDa}, 46-\mathrm{kDa}$ and $31-$ $\mathrm{kDa}$, respectively, after Coomassie Blue staining. The yield of the recombinant protein was approximately 1 mg from a 1 liter culture. The protein was concentrated with a Centriprep-30 concentrator (Amicon, Beverly, MA, U.S.A.).

MAbs specific for hsp70:

BALB/c mice were immunized with purified recombinant $T$. gondii hsp70 fusion protein in complete Freund's adjuvant. The booster immunization was performed using the same antigen in incomplete Freund's adjuvant. Spleen cells from the primed mice were fused with SP2/0-Ag14 cells using a cell fusion apparatus type SSH-1 (Shimadzu Co., Kyoto) according to the manufacturer's protocol. Fused cells were selected in medium containing HAT, and the supernatants of the cultures were tested for the presence of anti-hsp70 mAb by ELISA as well as by immunoprecipitation of hsp70 from $T$. gondii lysate. Positive hybridomas were cloned by the limiting dilution method. A mAb specific for human hsp70, 1E11, was generated by the same method except the fusion was performed using polyethylene glycol. The rat anti-hsp70 mAb 7.10 (Kurtz et al., 1986) was purchased from Affinity BioReagents, Inc. (Neshanic Station, NJ, U.S.A.).

\section{ELISA:}

The enzyme-linked immunoadsorbent assay was performed as described (Hornbeck, 1996). Briefly, flat bottom microtiter plates (Dynatech, Zug, Switzerland) were coated with recombinant hsp70 protein and soluble tachyzoite Ags in PBS at a concentration of 2 and 40 $\mu \mathrm{g} / \mathrm{m} l$, respectively, at $4^{\circ} \mathrm{C}$ for more than $24 \mathrm{hr}$. Plates were blocked with blocking buffer (borate buffered saline containing 0.05\% Tween 20, 1 mM EDTA, 0.25\% BSA and $0.05 \% \mathrm{NaN}_{3}$ ), and then incubated with the first antibody. After washing, each well was incubated with alkaline phosphate conjugated anti-mouse Igs ( $\gamma$ and $\mathrm{L}$ chain specific) (Tago, Camarillo, CA, U.S.A.) and washed with distilled water before incubation with $\mathrm{p}$ nitrophenyl phosphate substrate solution. Soluble tachyzoite Ags were prepared by extensive dialysis of the lysate of $T$. gondii RH strain tachyzoites with PBS.

\section{Western blotting:}

Western blot analysis of hsp70 expression was performed as previously described with a slight modification (Tamura and Yui, 1995). Briefly, protein lysates of $T$. gondii $\left(7.5 \times 10^{8}\right.$ cells $\left./ \mathrm{m} l\right)$ and the human B cell line ARH $\left(2.5 \times 10^{7} / \mathrm{m} l\right)$ were prepared in lysis buffer containing $300 \mathrm{mM} \mathrm{NaCl}, 50 \mathrm{mM}$ Tris $\cdot \mathrm{HCl}$ (pH7.5), 0. $5 \%$ Triton $\mathrm{X}-100,10 \mu \mathrm{g} / \mathrm{m} l$ leupeptin, $10 \mu \mathrm{g} / \mathrm{m} l$ pepstatin A and $1 \mathrm{mM} \mathrm{PMSF}$, and centrifuged at $10,000 \times g$ for $15 \mathrm{~min}$ to remove nuclei. Each sample was separated by $10 \%$ SDS-PAGE and electroblotted onto a nitrocellulose membrane (NitroBind; MSl, Westboro, MA). Blots were blocked with $10 \%$ milk in Tris-buffered saline ( $\mathrm{pH}$ 7.6) containing $0.1 \%$ Tween 20 (TBST), probed with anti-hsp70 mAbs in TBST for $1 \mathrm{hr}$, incubated with biotinylated anti-mouse or anti-rat IgG $\mathrm{Ab}$ (Jackson ImmunoResearch, West Grove, PA, U.S.A.) at 1:2,000 for $1 \mathrm{hr}$, and incubated with horseradish peroxidase-conjugated streptavidin (Zymed Laboratories, San Francisco, CA, U.S.A.) at 1:3,000 for $30 \mathrm{~min}$. Protein bands were visualized using an ECL detection system (Amersham, Buckinghamshire, England) according to the manufacturer's specifications.

In some experiments, protein purified by immunoprecipitation was used for Western blot analysis. Immunoprecipitation was performed as previously described with some modifications (Yui et al., 1988). Briefly, cells were lysed in lysis buffer containing $0.5 \%$ 
GCGCAAAGGA GTGTAGAAGA TGCATTGTTC GGTCAAGTAT CTGCAAGAAA GAAAGGCTTT CGGAAAGAA ACCGGGGCTC 80 TGCAAGAAAT TGCCAGTGTG TTTCGTCTTT TTTGGCTTGA ACAGCGAGAT TTGCACCGTG TGCTGCCTCC GCAGCACGGA 160 CAAGTTGCTC CCAGCACCTA CGTCCGAGTA CATACCACAC ACCGCCCTCT TCGTCCCTCA TCATCCCCTG CTGCTGCGCG 240 GGTGTGCTGT CCGGTACGAG TCATAGGGTG TGTCCGGCAC TCGCCCCGCA TTTCATCTTT AGGAGAGTGC CGTTCCGTGC 320 GGTGCAGCTC AAACTAAGGA CGGATCGAAG GTCAGTGTTT TTTCCTTCCA ACCATTTTTC CTTTTCCACT CCCCCGTTCT 400 TTTTTGTGTC GCGTTGCAGT

1

10

CGTTTGTCCC TGCAGAAGAC AAC ATG GCG GAC TCT CCT GCT GTG GGT ATT GAC CTT GGC ACC ACC TAT MET ala asp ser pro ala val gly ile asp leu gly thr thr tyr

TCT TGC GTA GGT GTG TGG AAG AAC GAT GCT GTG GAA ATC ATC GCG AAC GAC CAG GGA AAC AGG ACG ser cys val glu val trp lys asn asp ala val glu ile ile ala asn asp gln gly asn arg thr

ACC CCG TCC TAC GTC GCG TTC ACC GAC ACG GAG AGA CTT GTC GGT GAT GCT GCG AAg AAC CAA GTC thr pro ser tyr val ala phe thr asp thr glu arg leu val gly asp ala ala lys asn gln val $60 \quad 70 \quad 80$ GCA CGC AAC CCG GAA AAC ACC ATT TTC GAT GCC AAG CGC CTA ATC GGT CGC AAg TTT GAT GAT CCC ala arg asn pro glu asn thr ile phe asp ala lys arg leu ile gly arg lys phe asp asp pro 90 100

TCG GTC CAG TCG GAC ATG AAG CAT TGG CCA TTC AAg GTC ATT GCT GGT CCG GGA GAC AAg CCC CTC ser val gln ser asp met lys his trp pro phe lys val ile ala gly pro gly asp lys pro leu

ATT GAA GTC ACG TAC CAG GGA GAG AAG AAG ACG TTC CAC CCT GAA GAG GTT TGC GCC ATG GTT TTG ile glu val thr tyr gln gly glu lys lys thr phe his pro glu glu val ser ala met val leu

GGC AAA ATG AAG GAA ATC GCG GAG GCT TAC CTC GGC AAG GAA GTG AAG GAG GCC GTC ATT ACC GTT gly lys met lys glu ile ala glu ala tyr leu gly lys glu val lys glu ala val ile thr val 150 160 CCT GCG TAC TTC AAC GAT TCG CAG CGT CAG GCT ACC AAG GAT GCT GGT ACC ATT GCC GGC CTC AGC pro ala tyr phe asn asp asr gin arg gln ala thr lys asp ala gly thr ile ala gly leu ser $170 \quad 180 \quad 190$ GTC CTC CGC ATT ATC AAC GAG CCC ACA GCG GCT GCC ATT GCT TAT GGT CTG GAC AAG AAG GGC TGC val leu arg ile ile asn glu pro thr ala ala ala ile ala tyr gly leu asp lys lys gly cys

GGT GAG ATG AAC GTC CTC ATC TTC GAC ATG GGT GGC GGT ACG TTC GAT GTG TCG CTG CTT ACA ATC gly glu met asn val leu ile phe asp met gly gly gly thr phe asp val ser leu leu thr ile

GAA GAC GGT ATC TTT GAA GTC AAG GCC ACC GCT GGT GAC ACC CAT CTT GGT GGT GAA GAT TTC GAC 1148 giu asp gly ile phe glu val lys ala thr ala gly asp thr his leu gly gly glu asp phe asp asn arg leu val asp phe cys val gln asp phe lys arg lys asn arg gly lys asp ile ser thr

AAC AGC CGT GCC CTT CGT CGC CTG CGT ACC CAG TGC GAG CGC ACC AAG AGA ACT CTC TCT AGC AGC asn ser arg ala leu arg arg leu arg thr gln cys glu arg thr lys arg thr leu ser ser ser
280
290
300

ACT CAG GCA ACC ATC GAA ATT GAC TCT CTT TTT GAG GGC ATT GAC TAC TCT GTG TCT ATC TCT CGT 1346 thr gln ala thr ile glu ile asp ser leu phe glu gly ile asp tyr ser val ser ile ser arg 310 320

GCG CGC TTT GAG GAG CTT TGC ATG GAC TAC TTC CGC AAC TCC CTG TTG CCC GTC GAG AAg GTC CTC 1412 ala arg phe glu glu leu cys met asp tyr phe arg asn ser leu leu pro val glu lys val leu

Figure 1 Nucleotide sequence of the $T$. gondii hsp70 cDNA. Nucleotides are numbered on the right margin and amino acids above the nucleotide sequence. The sequence contains the following underlined elements: (A) potential glycosylation sites; (B) GGMP repeats; (C) AATAAT polyadenylation signal-like sequence. Both strands of the subcloned cDNA in pBluescript SKII $(+)$ were completely sequenced. 
lys asp ser gly ile asp lys arg ser val ser glu val val leu val gly gly ser thr arg ile 350

360

CCC AAg ATT CAG CAG CTC ATC ACT GAC TTC TTC AAC GGA AAG GAG CCG TGC AGg TCG ATC AAC CCC 1544 pro lys ile gln gln leu ile thr asp phe phe asn gly lys glu pro cys arg ser ile asn pro 370

380

GAT GAG GCC GTT GCG TAC GGT GCT GCT GTC CAG GCA GCG ATC TTG AAG GGA GTT ACC AGC TCT CAG 1610 asp glu ala val ala tyr gly ala ala val gln ala ala ile leu lys gly val thr ger ger gln

$390 \quad 400 \quad 410$

GTG CAG GAT TTG CTT CTT CTG GAT GTT GCG CCT CTC TCT CTC GGT CTG GAG ACA GCT GGT GGT GTC 1676 val gln asp leu leu leu leu asp val ala pro leu ser leu gly leu glu thr ala gly gly val

420

430

ATG ACC AAg CTG ATT GAA AGA AAC ACA ACG ATC CCG ACC AAg AAg TCT CAG ACC TTC ACC ACG TAC 1742 met thr lys leu ile glu arg asn thr thr ile pro thr lys lys ser gln thr phe thr thr tyr

440

450

GCG GAC AAC CAG CCA GGA GTG CTG ATT CAG GTG TAC GAA GGT GAG CGT GCG ATG ACC AAA GAC AAC 1808 ala asp asn gln pro gly val leu ile gln val tyr glu gly glu arg ala met thr lys asp asn

460

470

AAC CTC CTG GGC AAA TTC CAC CTG GAT GGT ATC CCC CCC GCC CCC CGT GGT GTC CCC CAA ATC GAA asn leu leu gly lys phe his leu asp gly ile pro pro ala pro arg gly val pro gln ile glu

480

490

GTC ACT TTC GAT ATC GAC GCT AAC GGT ATC ATG AAC GTC ACA GCG CAA GAC AAG TCC ACC GGA AAG val thr phe asp ile asp ala asn gly ile met asn val thr ala gln asp lys ser thr gly lys 500 510 520 AGC AAC CAA ATC ACC ATC ACG AAC GAC AAG GGC CGC CTC AGT GCG TCC GAA ATC GAC CGC ATG GTG 2006 ser asn gln ile thr ile thr asn asp ils gly arg leu ser ala ser glu ile asp arg met val

CAA GAG GCA GAG AAG TAC AAA GCC GAA GAC GAA CAG AAC AAG CAC CGT GTG GAG GCG AAG AAT GGC 2072 gln glu ala glu lys tyr lys ala glu asp glu gln asn lys his arg val glu ala lys asn gly

550

560

CTG GAG AAC TAC TGC TAC CAC ATG AGA CAG ACC TTG GAT GAC GAG Aag CTT AAg GAC AAg ATC TCC 2138 leu glu asn tyr cys tyr his met arg gln thr leu asp asp glu lys leu lys asp lys ile ser

570

580

TCT GAG GAC AGA GAC ACT GCC AAC AAG GCC ATC CAG GAG GCC CTT GAC TGG CTG GAC AAG AAC CAA 2204 ser glu asp arg asp thr ala asn lys ala ile gln glu ala leu asp trp leu asp lys asn gln

590

600

CTA GCA GAG AAg GAG GAA TTC GAG GCG AAG CAG AAg GAA GTT GAG TCC GTC TGC ACA CCA ATC ATC leu ala glu lys glu glu phe glu ala lys gln lys glu val glu ser val cys thr pro ile ile

610

ACC AAG CTG TAC CAG GCA GGT GCG GCT GCA GGT GGC ATG CCT GGT GGT ATG GGC GGT ATG CCT GGT 2336 thr lys leu tyr gln ala gly ala ala ala gly gly met pro gly gly met qly qly met pro gly

640

650

GGT ATG GGC GGT ATG CCT GGT GGT ATG GGC GGT ATG CCC GGC GGG ATG GGC GGT ATG CCC GGT GCA 2402 gly met qly gly met pro gly gly met gly gly met pro gly qly met qly gly met pro gly ala

660

GGC ATG GGA GGC TCT GGC GGC CCC ACC GTG GAG GAA GTT GAT

gly met gly gly ser gly qly pro thr val glu glu val asp

TAACTGTTGA AACGGAAAGA AGTGAACAAA AACCCCATGT GACGTGACAG TTTTTGGGTT CTTCGGAAGA AGAAAGTAAC 2524 CGGAGTTTTG ACTTCTCTCC AGTAGTGGTG TATCGCACAT GCATCAACTT CCGTGGAAGA GAGGTTGAAG AGGGGGAGTC 2604 CTGGTGTATA TACACTGTGT GTATATATAA CATCAACTTC ATATTGTTTT CGAAAGTATC GAAGCATCAA CTTTCTCGCA 2684 AAAAGAAACC CTGCCACCTA TGTGGATGAG TCCCTTGCTG AATAATCCCT AATTC 
Triton-X and centrifuged to remove nuclei. Each sample was incubated with anti-hsp70 $\mathrm{mAb}$ at $4^{\circ} \mathrm{C}$ for $1 \mathrm{hr}$, and with protein A Sepharose (Sigma, St. Louis, MO, U. S.A.) for an additional $1 \mathrm{hr}$, washed, boiled with SDS sample buffer, and separated under reducing conditions by $10 \%$ SDS-PAGE. After electrophoresis, proteins were electroblotted onto a nitrocellulose membrane, and the presence of the specific proteins was detected using anti-hsp70 mAbs or mouse serum as described.

The GenBank accession number of the $T$. gondii hsp70 cDNA sequence is U82281.

\section{RESULTS}

Structure of $T$. gondii hsp70:

$T$. gondii hsp70 cDNA was cloned by screening a cDNA library derived from the tachyzoites of the $T$. gondii RH strain with the human hsp70 gene probe (Hunt and Morimoto, 1985). The entire nucleotide sequence (2739 base pairs) of the longest cDNA clone (pTH14) was determined (Fig. 1). The cDNA sequence contained a single large open reading frame predicting a 667 amino acid protein of 72,292 daltons. This coding region was flanked by 443 bp on the $5^{\prime}$ end and by 295 bp

T.g. MA---DS---D----AVGIDLGTTYSCVGVWKNDAVEIIANDQGNRTTPSYVAFT-DTERLVGDAAKNQVARNPENTIFDAKRLIGRKFDDPSVQSDMK 93

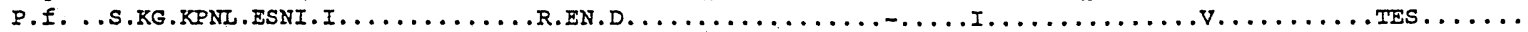

T.c. .

M.m. . -

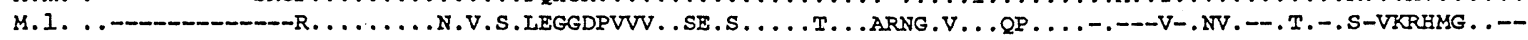

T.g. HWPFKVIAGPGDKPLIEVTYQGEKKTFHPEEVSAMVLGKMKE IAEAYLGKEVKEAVITVPAYFNDSQRQATKDAGTIAGLSVLRIINEPTAAAIAYGLDK 188

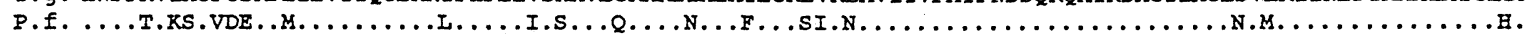

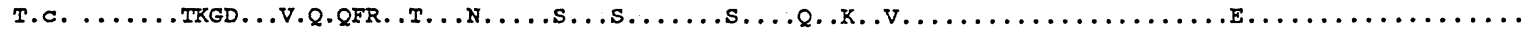

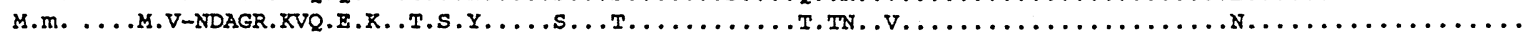

M.I. -.S-I-IX_.

T.g. KGCG-EMNVIFDMGGGTFDVSLITIEDGIFEVKATAGDTHLGGEDFDNRLVDFCVQDFKRKNRGKDISTNSRAIRRLRTQCERTKRTLSSSTQATIEID 286

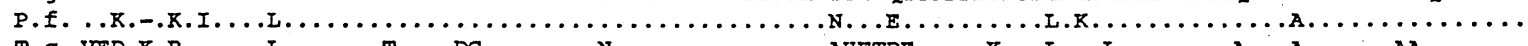

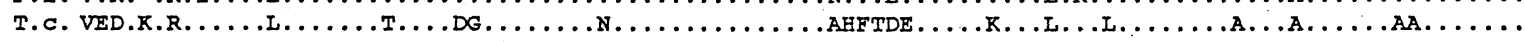

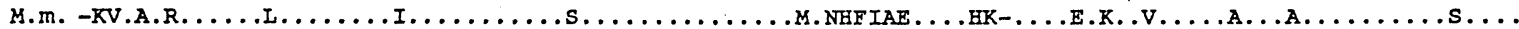

M.I. --GER.QTI.V..I........E.GE.VV..R..S..N...D.W.D.I.NWL.DK..-GTS.I.ITKDKM.MQ...EAA.KA.IE...QSTSVNLP

T.g. SLFEGID-_-_YSVSISRARFEELCMDYFRNSIIPVEKVLKDSGIDKRSVSEVVLVGGSTRIPKIQQLITDFFNGKEPCRSINPDEAVAYGAAVQAAIL 382

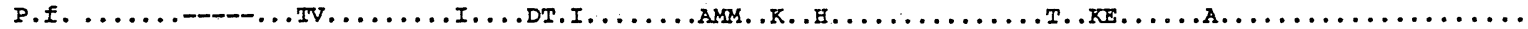

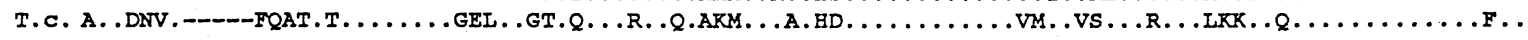

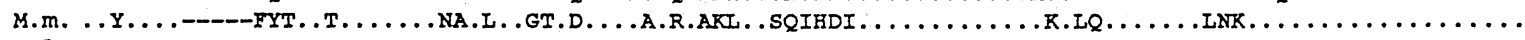

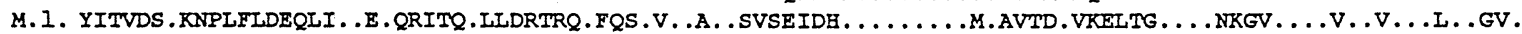

T.g. KGVTSSQVQDIILLDVAPLSLGLETAGGVMTKLIERNTTIPTKKSQTFTTYADNQPGVLIQVYEGERAMTKDNNLIGKFHLDGIPPAPRGVPQIEVTFDI 482

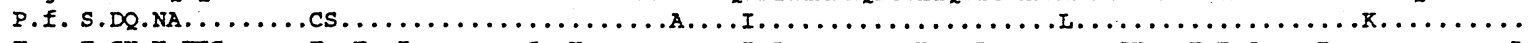

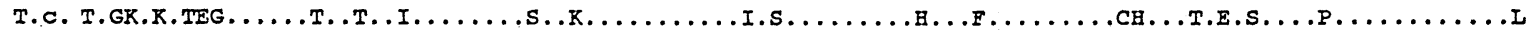

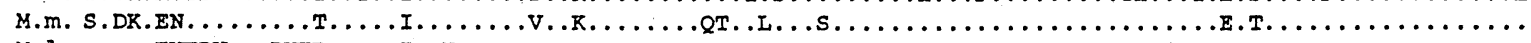

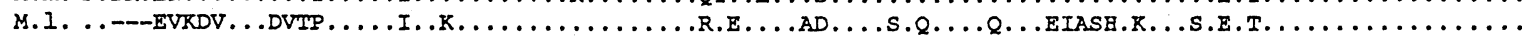

T.g. DANGIMNVTAQDKSTGKSNQITITNDKGRLSASE IDRMVQEAEKYKAEDEQNKHRVEAKNGLENYCYHMRQTLDDEKLKDKISSEDRDTANKAIQEAIDW 582

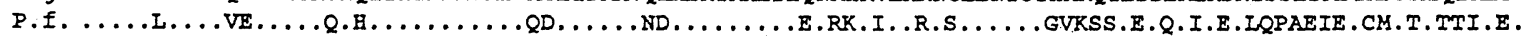

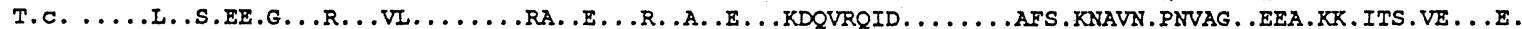

M.m. ..............E.K.........KED.E..........KQRDK.SS ..S..S.AFN.KA.VE ...QG .ND..KQKILDKCN.IIS.

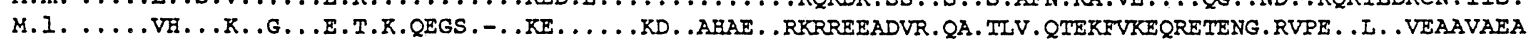

T.g. LDKNQLAEKEEFEARQKEVESVCTPIITKLYQ--AGAA-AGGMPGGM-GGMPGGM-GGMPG---G--MGGMPGGM-G-GMP-GAGMGGSGGPTVEEVD 667

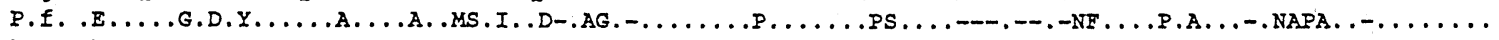

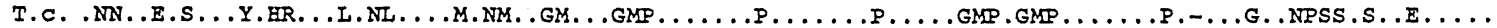

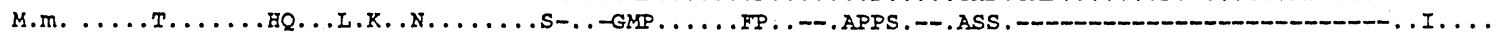

M. 1. KTALGGTDISAIKSAMEKLGQDSQALGQAI. EATQA.SKV. . -EASAP . . -SNSTDDVL-TRRWSTTN. SPK-

Figure 2 Alignment of amino acid sequences of $T$. gondii hsp70 (T.g.), P. falciparum hsp70 (P.f.) (Yang and Tan-Ariya, 1987), T. cruzi hsp70 (T.c.) (Engman and Dragon, 1990), L. donovani hsp70 (L.d.) (MacFarlane and Blaxter, 1990), mouse hsc70 (M.m.) (Giebel and Dworniczak, 1988), and M. leprae (M.I.) (McKenzie and Adams, 1991). The amino acid sequence of $T$. gondii hsp70 was predicted from the cDNA sequence of clone pTH14 (GenBank accession number U82281). Identical amino acids are indicated by asterisks. Gaps were introduced to maximize homology. Amino acids of T. gondii hsp70 are numbered on the right margin. 


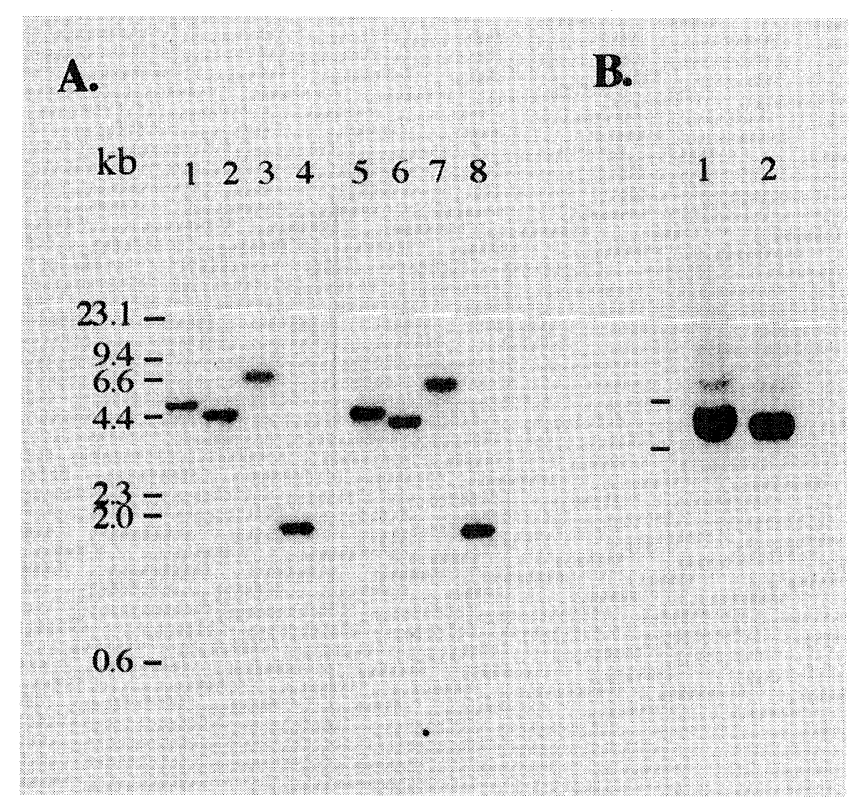

Figure 3 Southern and Northern blot analysis of $T$. gondii hsp70 gene.

A. Analysis of $T$. gondii hsp70 gene by Southern blotting. DNA $(3 \mu \mathrm{g})$ was cleaved with the restriction enzymes, Bam $\mathrm{Hl}(1,5)$, EcoRl (2, $6)$, Hind III $(3,7)$ and Pst I $(4,8)$. The blot was hybridized with a ${ }^{32} \mathrm{P}$-labeled Pst I-Kpn I fragment (nucleotides 430-935) (1-4) or a Pvu IIHind III fragment (nucleotides 1668-2123) (58) of pTH14 cDNA. The blot was washed under stringent conditions $(0.2 \times \mathrm{SSC} / 0.1 \% \mathrm{SDS}$ at $\left.65^{\circ} \mathrm{C}\right)$. Kilobases shown at left.

B. Northern blot analysis of hsp70 gene expression in cultured T. gondii tachyzoites. Total tachyzoite RNA $(5 \mu \mathrm{g})$ extracted from cultured tachyzoites (1) and tachyzoites heat shocked at $42^{\circ} \mathrm{C}$ for $2 \mathrm{hr}(2)$, was analyzed by blotting. The hsp70 probe was a Pst I-Kpn I fragment spanning the nucleotides $430-935$ of pTH14. The positions of rRNA are indicated at left.

on the 3'-untranslated end. The higher eukaryotic polyadenylation signal AATAAA was absent in the $3^{\prime}$ untranslated region of hsp70 cDNA. Instead, the AATAAT sequence was found 10 nucleotides upstream of the poly (A) tail. The deduced primary sequence was $80.8 \%, 72.3 \%, 72.3 \%$ and $74.1 \%$ homologous to P. falciparum hsp70 (Yang and Tan-Ariya, 1987), T. cruzi hsp70, L. donovani hsp70 (MacFarlane and Blaxter 1990), and human and rodent heat shock cognate proteins (hsc70) (Dworniczak and Mirault 1987; Giebel et al., 1988), respectively, indicating that this cDNA encodes $T$. gondii hsp70. The homology to $M$. leprae was $46.1 \%$. Inspection of the amino acid sequence revealed the absence of long hydrophobic stretches and the $\mathrm{N}$ - terminal signal sequence. There were three potential $\mathrm{N}$-linked glycosylation sites in the deduced amino acid sequence. At the C-terminal end, there were four complete and one incomplete GGMPGGM repeated sequences. Similar GGMP repeats are present in the majority of parasite hsp70 proteins as well as human and rodent hsc70 (Fig. 2). T. cruzi and P. falciparum hsp70 contain 9 and 5 GGMP repeats, respectively. Human and mouse hsc70 contain 2 repeats. The $\mathrm{C}-$ terminal regulatory motif, EEVD, was conserved as in hsp70s of other eukaryotic cells (Freeman et al., 1995).

The $T$. gondii gene encoding hsp70 was analyzed by Southern blotting (Fig. 3A). The DNA was digested with restriction enzymes and probed with two cDNA probes; one spanning nucleotides 430-935 (corresponding to amino acids Met-1 to Thr-164) and the other 1668-2123 (Thr-407 to Leu-560). These probes hybridized with the identical restriction fragments of the hsp70 gene. Only single bands of approximately 4.9, 4.5, 7.0 and $1.9 \mathrm{~kb}$ were detected in Bam Hl, Eco Rl, Hind III, and Pst I fragments of the DNA after high stringency washing $\left(0.1 \times \mathrm{SSC}, 0.1 \% \mathrm{SDS}\right.$ at $\left.65^{\circ} \mathrm{C}\right)$. The size of the Pst I fragment was identical to the distance between the two Pst I sites of the cDNA sequence (nucleotide 4312300 ), implying that there is no intron between these two sites. The blot was also washed at low stringency $(0.2 \times$ $\mathrm{SSC}, 0.1 \% \mathrm{SDS}$ at $20^{\circ} \mathrm{C}$ ) after hybridization, but no additional signals were detected. The expression of this

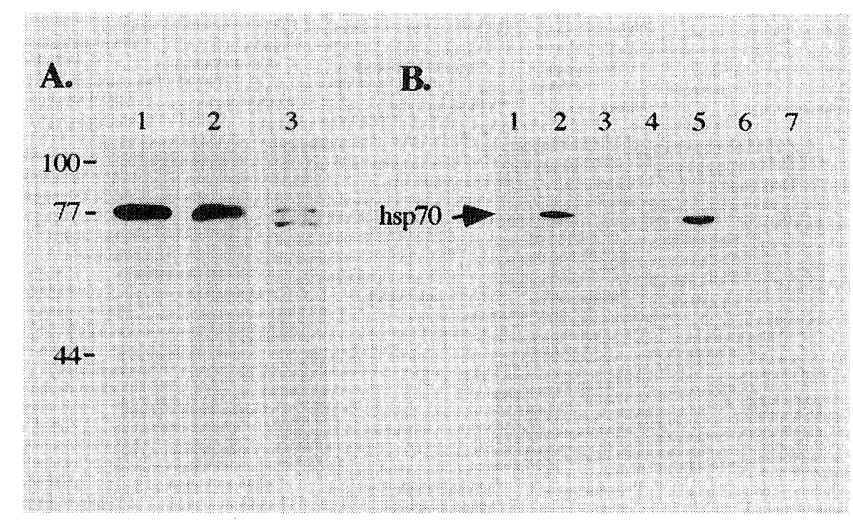

Figure 4 Identification of the native $T$. gondii hsp70 by mAbs.

A. Lysate of $T$. gondii $\mathrm{RH}$ strain tachyzoites was separated by $10 \%$ SDS-PAGE, blotted, and probed with $\mathrm{mAbs} \mathrm{T} \times \mathrm{D} 11$ (1), $\mathrm{T} \times \mathrm{A} 5$ (2) and 7.10 (3). Molecular weights are indicated on the left.

B. Lysate of $T$. gondii tachyzoites was immunoprecipitated with no $\mathrm{Ab}(1), \mathrm{T} \times \mathrm{D} 11(2), \mathrm{T} \times \mathrm{G} 3$ (3), $\mathrm{T} \times \mathrm{B} 12(4), \mathrm{T} \times \mathrm{H} 2 \quad(5), \mathrm{T} \times \mathrm{A} 5 \quad(6)$ and $1 \mathrm{E} 11$ (7); separated by $10 \%$ SDS-PAGE; blotted; and probed with anti-hsp70 mAb 7.10. 
Table 1 ELISA of anti-hsp70 mAbs produced in this study

\begin{tabular}{|c|c|c|c|c|c|c|}
\hline \multirow[b]{2}{*}{$\begin{array}{l}\text { Immuniza- } \\
\text { tion** }\end{array}$} & \multirow[b]{2}{*}{ Name } & \multirow[b]{2}{*}{ Isotype } & \multicolumn{4}{|c|}{$\begin{array}{c}\text { Binding of } \mathrm{mAb} \text { with recombinant proteins } \\
\text { prepared as* }\end{array}$} \\
\hline & & & $\begin{array}{l}\text { T. gondii } \\
\text { hsp70 }\end{array}$ & $\begin{array}{l}\mathrm{N} \text {-terminal } \\
\text { fragment }\end{array}$ & $\begin{array}{l}\text { C-terminal } \\
\text { fragment }\end{array}$ & $\begin{array}{l}\text { human } \\
\text { hsp70 }\end{array}$ \\
\hline \multirow[t]{5}{*}{ hsp70 } & $\mathrm{T} \times \mathrm{D} 11$ & $\gamma 2 \mathrm{~b}$ & + & - & + & - \\
\hline & $\mathrm{T} \times \mathrm{G} 3$ & $\gamma 1$ & + & - & + & - \\
\hline & $\mathrm{T} \times \mathrm{B} 12$ & $\gamma 1$ & + & - & + & - \\
\hline & $\mathrm{T} \times \mathrm{H} 2$ & $\gamma 2 \mathrm{a}$ & + & - & + & - \\
\hline & $\mathrm{T} \times \mathrm{A} 5$ & $\gamma 1$ & + & + & - & + \\
\hline $\begin{array}{l}\text { human } \\
\text { hsp70 }\end{array}$ & $1 \mathrm{E} 11$ & $\gamma 2 \mathrm{~b}$ & - & N.D. ${ }^{* * *}$ & N.D. & + \\
\hline \multicolumn{7}{|c|}{$\begin{array}{l}\text { *The specificity of each } \mathrm{mAb} \text { was tested by ELISA using total } T \text {. gondii hsp } 70, \mathrm{~N}-\text { as well as C- } \\
\text { terminal fragments of the hsp } 70 \text {, and human hsp } 70 \text { recombinant proteins. } \\
\text { The results were measured using plate reader with a } 405 \mathrm{~nm} \text { filter. } \\
+ \text { indicates positive results. -indicates the value is within the mean value of the control (without } \\
\text { Ab) } \pm \text { standard error of the mean. } \\
{ }^{* *} \mathrm{BALB} / \mathrm{c} \text { mice were immunized with recombinant } T \text {. gondii hsp } 70 \text { or human hsp70 protein. After } \\
\text { fusion of spleen cells with SP2, hybridoma supernatants were screened by ELISA using the same } \\
\text { antigen. }\end{array}$} \\
\hline
\end{tabular}

gene was determined by Northern blot analysis (Fig. $3 \mathrm{~B})$. There was no significant increase in the expression level of hsp70 RNA after treatment of the tachyzoites at $42^{\circ} \mathrm{C}$ for $2 \mathrm{hr}$.

Identification of $T$. gondii hsp70 by mAbs:

cDNA (pTH14) was expressed in E. coli as a tagged protein carrying six histidine residues at its $\mathrm{N}$ terminal, and was purified by immobilized nickel affinity chromatography. Mice were immunized with this recombinant protein and spleen cells were fused with SP2 cells to produce hybridomas. The initial screening of the hybridoma supernatant was performed by ELISA using the recombinant protein. The hybridomas secreting specific antibodies were further screened for their ability to bind to natural $T$. gondii protein. $T$. gondii lysate was immunoprecipitated with each hybridoma supernatant, separated on SDS-PAGE, blotted, and probed with antisera of the immunized mice. Five hybridomas producing $\mathrm{mAb}$ that can bind recombinant as well as natural $T$. gondii protein were cloned by limiting dilution (Table 1 ). Western blot analysis was performed to determine the $T$. gondii protein detected by these mAbs (Fig. 4). $\mathrm{T} \times \mathrm{D} 11$ and $\mathrm{T} \times \mathrm{A} 5$ bound only an $\sim 77-\mathrm{kDa}$ protein in the $T$. gondii lysate. Anti-hsp70 $\mathrm{mAb} 7.10$ which is widely cross-reactive with members of the hsp70 family including hsp70, hsc72, grp78 and heat inducible hsp72 (Kurtz and Rossi, 1986) detected the $\sim 77$ - and $\sim 72-\mathrm{kDa}$ proteins expressed in $T$. gondii tachyzoites. To determine whether $\sim 77-\mathrm{kDa} T$. gondii protein identified by our $\mathrm{mAbs}$ is identical to that detected by anti-hsp70 mAb 7.10, T. gondii lysate was immunoprecipitated with the panel of mAbs, separated on SDS-PAGE, blotted, and was probed with 7.10. All of them specifically precipitated the $\sim 77-\mathrm{kDa}$ protein from $T$. gondii lysate that can bind to 7.10, although the intensities of the bands were not equivalent (Fig. 4B). Since this was the only band that could be detected by $\mathrm{T} \times \mathrm{D} 11$ and $\mathrm{T} \times \mathrm{A} 5$, we concluded that these mAbs specifically bind to the natural hsp70 expressed in $T$. gondii. The expression of this protein was not signifi-

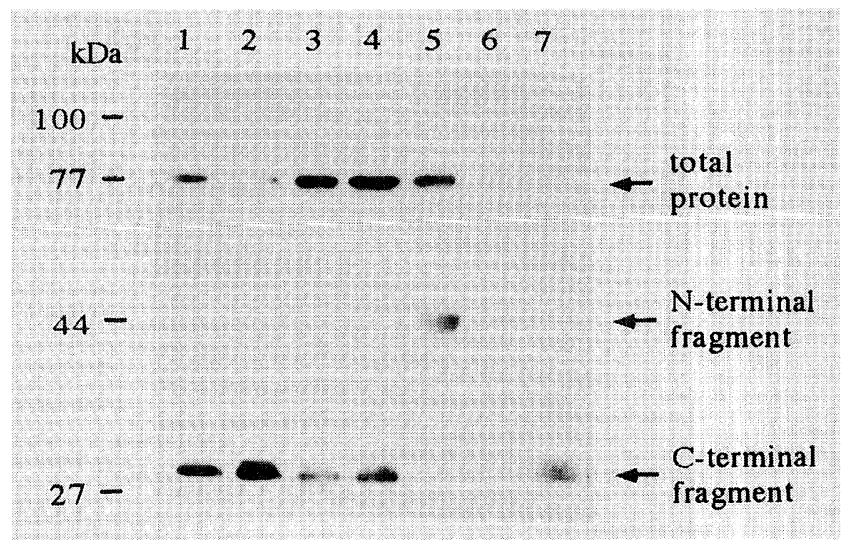

Figure 5 Western blot analysis of the specificity of antihsp70 mAbs to recombinant hsp70 fragments. The mixture of purified recombinant hsp70, $\mathrm{N}$ - and Cterminal fragments was separated by $10 \%$ SDSPAGE. After blotting, lanes were cut and each strip was probed with $\mathrm{mAb} \mathrm{T} \times \mathrm{D} 11$ (1), $\mathrm{T} \times \mathrm{G} 3$ (2), $\mathrm{T} \times \mathrm{B} 12(3), \mathrm{T} \times \mathrm{H} 2(4), \mathrm{T} \times \mathrm{A} 5$ (5), $1 \mathrm{E} 11$ (6) and 7.10 (7). Molecular weights are indicated on the left. 


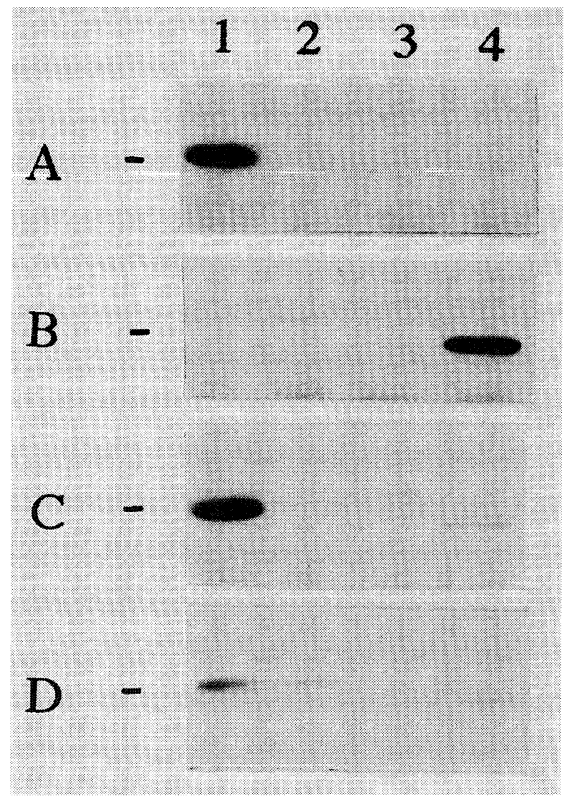

Figure 6 Immunoprecipitation of $T$. gondii hsp70s by $\mathrm{T} \times$ D11 and by 1E11. Cell lysates of $T$. gondii tachyzoites $(1,2)$ and the human B cell line ARH $(3,4)$ were immunoprecipitated with $\mathrm{T} \times \mathrm{D} 11(1,3)$ or 1E11 $(2,4)$. Each precipitated sample was split into 4 groups and separated by $10 \%$ SDS-PAGE generating 4 identical gels (A-D). Each gel was blotted onto a nitrocellulose membrane and probed with $\mathrm{T} \times \mathrm{D} 11(\mathrm{~A}), 1 \mathrm{E} 11(\mathrm{~B}), \mathrm{T} \times \mathrm{A} 5(\mathrm{C})$ and 7.10 (D). The position of the $77-\mathrm{kDa}$ molecular size marker is indicated as $(-)$.

cantly altered after treatment of $T$. gondii for 2,4 , or 6 hrs at $42^{\circ} \mathrm{C}$ (data not shown). MAb1E11, which was originally generated using recombinant human hsp70, also precipitated the protein of the same molecular weight that can bind to 7.10 (Fig. 4B). This protein, however, was not identical to hsp70 detected by $T$. gondii hsp70 specific $\mathrm{mAb} \mathrm{T} \times \mathrm{D} 11$, as will be discussed later.

Proteins of the hsp70 family consist of two domain structures: an $\mathrm{N}$-terminal ATPase and a C-terminal peptide-binding domain (Chappell et al., 1987). To determine the domain to which these mAbs bind, we created recombinant $\mathrm{N}$-terminal and C-terminal hsp70 peptides both tagged with six histidine residues. The $\mathrm{N}$-terminal fragment spanned from amino acid Ala-2 to Gly-404, and the C-terminal fragment from Leu-405 to Asp-667. These peptides were affinity purified using nickel chromatography and were used for ELISA and Western blot assays (Table 1, Fig. 5). Of $5 \mathrm{mAbs}$ specific for the hsp70, $4 \mathrm{mAbs}$ bound to the C-terminal peptide binding domain and $1 \mathrm{mAb}, \mathrm{T} \times \mathrm{A} 5$, bound to the

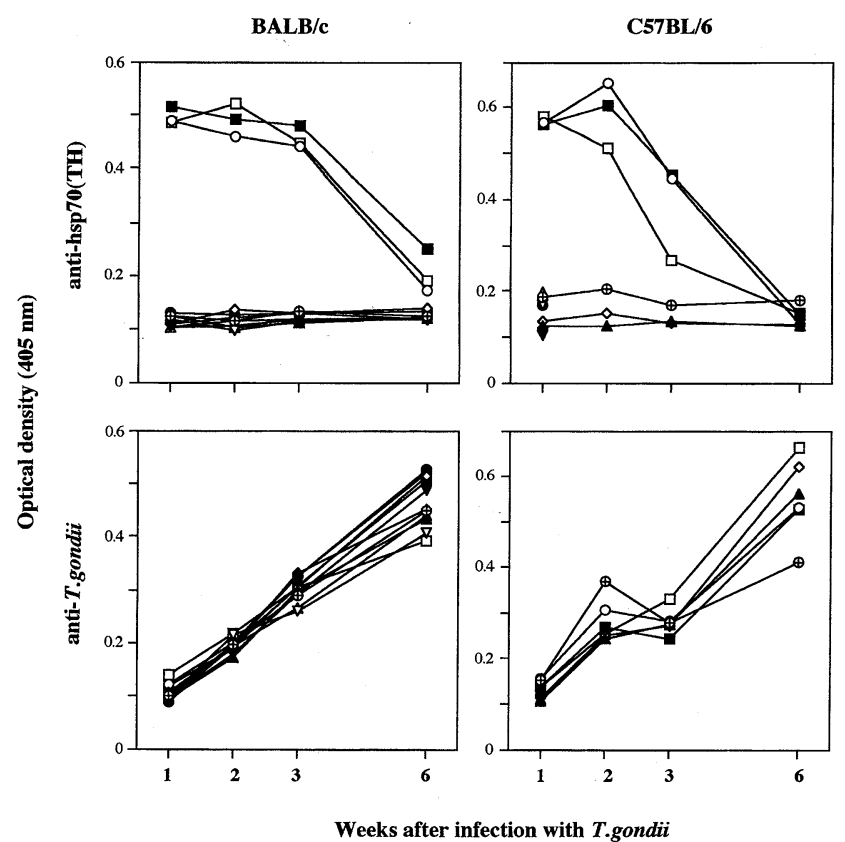

Figure 7 ELISA of anti-hsp70 $\mathrm{Ab}$ in the serum of mice infected with $T$. gondii. Serum samples were obtained from each of $11 \mathrm{BALB} / \mathrm{c}$ and $\mathrm{C} 57 \mathrm{BL} / 6$ mice $1,2,3$, and 6 weeks after oral infection with 20 cysts of $T$. gondii Fukaya strain as indicated. The levels of antibody against hsp70 and soluble tachyzoite antigens were determined by ELISA as described in Materials and Methods. Serum samples were used at 1:50 dilution. The means of triplicate or duplicate experiments are shown. Five C57BL/ 6 mice died between 1 and 2 weeks after infection.

$\mathrm{N}$-terminal ATPase domain. Interestingly, $\mathrm{T} \times \mathrm{A} 5 \mathrm{mAb}$ cross-reacted with recombinant human hsp70, while none of the other $4 \mathrm{mAbs}$ bound to it (Table 1). Antihuman hsp70 mAb, 1E11, did not cross-react with the recombinant $T$. gondii hsp70 protein. The $7.10 \mathrm{mAb}$ bound to the $\mathrm{C}$-terminal fragment of the recombinant hsp70 protein (Fig. 5).

Distinction of $T$. gondii hsp70s precipitated by $\mathrm{T} \times \mathrm{D} 11$ and $1 \mathrm{E} 11 \mathrm{mAbs}$ :

Although Western blot analysis of $T$. gondii hsp70 indicated that $1 \mathrm{E} 11$ can bind to the hsp70-like molecule expressed in T. gondii (Fig. 4), 1E11 did not bind to the recombinant hsp70 (Fig. 5). To determine that the molecule detected by $1 \mathrm{E} 11 \mathrm{mAbs}$ is distinct from the cloned hsp70 gene product, each protein was purified by immunoprecipitation with $1 \mathrm{E} 11$ and $\mathrm{T} \times \mathrm{D} 11 \mathrm{mAb}$. The precipitated materials were split into four groups, separated by SDS-PAGE, blotted, and probed with four distinct anti-hsp70 mAbs, T $\times$ D11, 1E11, T $\times$ A5 and 7.10 (Fig. 6). Human hsp70 was used as a control for the 


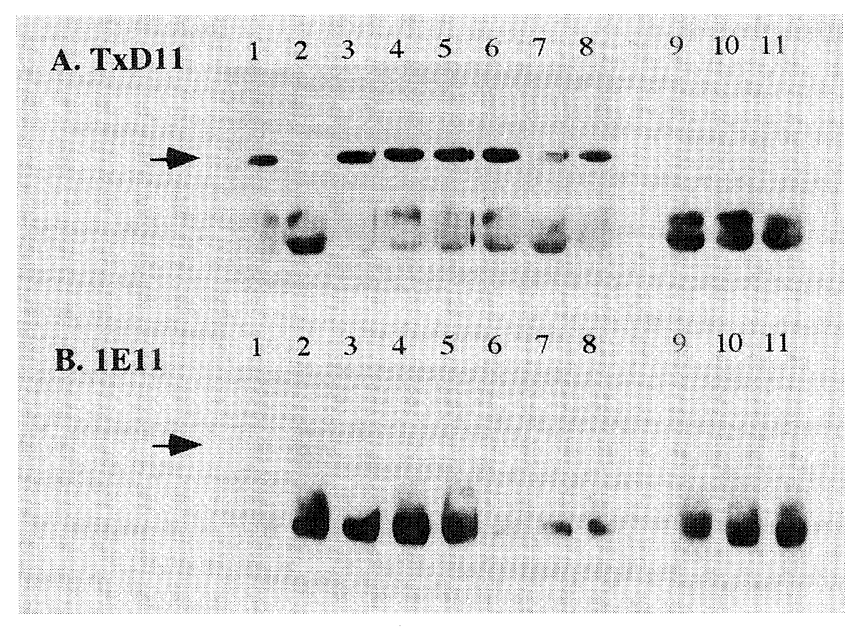

Figure 8 Western blot analysis of anti-hsp70 $\mathrm{Ab}$ in the serum of mice infected with $T$. gondii. Lysate of $T$. gondii tachyzoites was immunoprecipitated with $\mathrm{T} \times \mathrm{D} 11$ (A.) or $1 \mathrm{E} 11$ (B.) and separated on 10\% SDS-PAGE. After blotting, lanes were separated and each strip was probed with $\mathrm{mAb} \mathrm{T} \times \mathrm{D} 11$ (1), 1E11 (2), sera from individual BALB/c (3-5) or $\mathrm{C} 57 \mathrm{BL} / 6$ (6-8) mice infected for 1 week, and BALB/c mice (9-10) infected for 6 weeks. Serum samples from mice which produced detectable levels of anti-hsp70 Ab by ELISA were used in this experiment.

immunoprecipitation. The protein precipitated by $\mathrm{T} \times$ D11 was detected by $\mathrm{T} \times \mathrm{A} 5$ and $7.10 \mathrm{mAb}$, but not by 1E11. 1E11 precipitated a T. gondii protein as detected by itself (B-2) and $7.10 \mathrm{mAb}(\mathrm{D}-2)$, although the intensity of the band was weak. This molecule is likely another member of the hsp70 family, because it can bind to anti-hsp70 mAbs 1E11 and 7.10, and because it has a molecular weight similar to the cloned hsp70. This hsp70-like molecule is not humam hsp70 that could have contaminated during the propagation of $T$. gondii in vitro, because the molecular weight of the $T$. gondii protein precipitated by $1 \mathrm{E} 11$ was larger than that of the human hsp70 (B-4). MAbs $\mathrm{T} \times \mathrm{D} 11$ and $\mathrm{T} \times \mathrm{A} 5$ did not bind to this protein $(\mathrm{A}-2, \mathrm{C}-2)$. These reslts suggest that $T$. gondii tachyzoites express another hsp70-like protein in addition to the cloned hsp70. These two molecules can be specifically identified by $\mathrm{T} \times \mathrm{D} 11$ and $1 \mathrm{E} 11 \mathrm{mAb}$.

Detection of anti-hsp70 Ab in the serum of $T$. gondii infected mice:

Pathogen-derived hsp70s have been shown to be strongly immunogenic to the host immune system in several infectious diseases. To determine whether $T$. gondii hsp70 can be a target of the host immune responses, we examined whether anti-hsp70 Ab can be

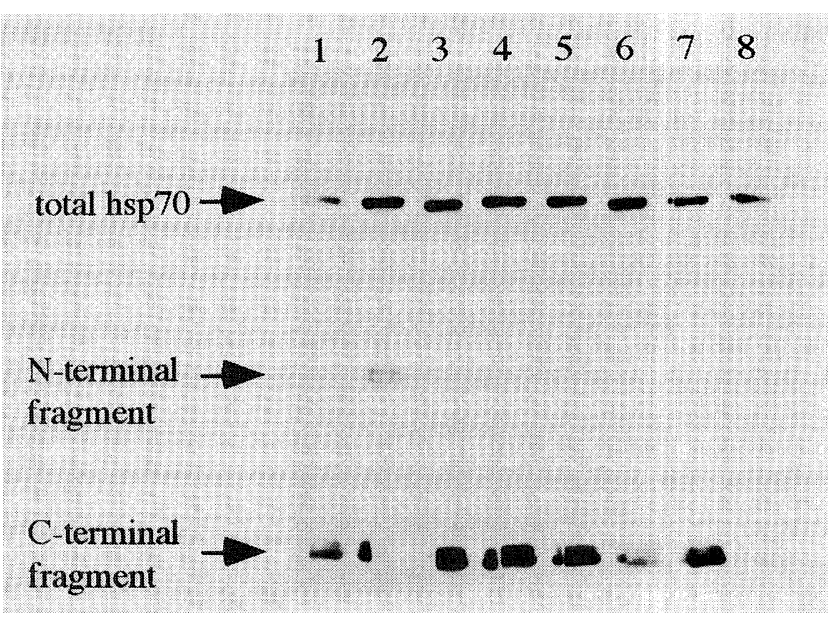

Figure 9 Western blot analysis of the specificity of antihsp70 serum from infected mice. The experiment was performed as described in the legend of Fig. 5. The blot of total $T$. gondii recombinant hsp70 as well as $\mathrm{N}$-terminal and $\mathrm{C}$-terminal fragments of hsp70 was cut, and each strip was probed with $\mathrm{mAb} \mathrm{T} \times \mathrm{D} 11$ (1), $\mathrm{T} \times \mathrm{A} 5$ (2), serum from individual BALB/c (3-5) or B6 (6-8) mouse infected for 1 week. The serum samples used here were identical to those used in Fig. 8.

detected in the serum of mice infected with $T$. gondii. $\mathrm{BALB} / \mathrm{c}$ and $\mathrm{C} 57 \mathrm{BL} / 6$ mice were infected with the low virulence Fukaya strain of $T$. gondii, and serum samples were collected $1,2,3$, and 6 weeks after infection. ELISA of these samples was performed using plates coated with the recombinant hsp70 (Fig. 7). Antibody to soluble tachyzoite antigens was also examined as a control. In both $\mathrm{BALB} / \mathrm{c}$ and $\mathrm{C} 57 \mathrm{BL} / 6$ mice, significant levels of anti-hsp70 antibody were detected in the sera of 3 out of 11 mice infected. The antibody levels were maintained for 2-3 weeks and gradually declined thereafter. Six weeks after infection, the serum Ab levels became nearly undetectable in $\mathrm{C} 57 \mathrm{BL} / 6$ mice. In contrast, the levels of serum antibody specific for soluble tachyzoite antigens continued to increase during the infection in all mice we have examined. During the course of the study, 5 C57BL/ 6 mice died between 1 and 2 weeks of infection. Interestingly, all 3 mice which developed anti-hsp70 antibody survived while only 3 out of 8 mice which did not developed anti-hsp70 antibody did. Therefore, to determine whether there is any correlation between the ability to produce anti-hsp70 Ab and protection against $T$. gondii infection, we sacrificed these C57BL/6 mice 7 weeks after infection and determined the number of brain cysts. There was, however, no significant difference in the cyst number between the 
mice which developed an anti-hsp70 antibody response $(803 \pm 153$ cysts/brain) and those which did not $(790 \pm$ 361 cysts/brain).

Characterization of the anti-hsp70 antibody in $T$. gondiiinfected mouse serum:

To determine that the anti-hsp70 antibody detected in the serum from infected mice by ELISA did indeed bind to the natural $T$. gondii protein, we purified native hsp70 by immunoprecipitation with $\mathrm{T} \times \mathrm{D} 11$, separated it on SDS-PAGE, blotted and probed with the serum from the infected mice (Fig. 8A). As expected, the antisera obtained from mice one week after infection bound to the natural $T$. gondii hsp70. The antisera from the same mice 6 weeks after infection barely bound to this protein. In a parallel study, we also determined whether these sera contained antibody specific for the hsp70-like protein purified by $1 \mathrm{E} 11 \mathrm{mAb}$. The protein isolated from $T$. gondii by immunoprecipitation with $1 \mathrm{E} 11 \mathrm{mAb}$ was probed with the same sera as used for the detection of hsp70 (Fig. 8B). These sera did not show any significant binding to hsp70-like protein purified by $1 \mathrm{E} 11 \mathrm{mAb}$. Finally, to determine whether anti-hsp70 antibody in the sera of the infected mice bound to the ATPase or peptide binding domain of the protein, recombinant $\mathrm{N}$ terminal and C-terminal fragments of hsp70 were used for the Western blot assay (Fig. 9). All 6 serum samples from both $\mathrm{BALB} / \mathrm{c}$ and $\mathrm{C} 57 \mathrm{BL} / 6$ mice bound to the $\mathrm{C}-$ terminal but not to the $\mathrm{N}$-terminal fragment of hsp70, indicating that the major antigenic determinant exists in the C-terminal portion of hsp70.

\section{DISCUSSION}

Full length cDNA encoding $T$. gondii hsp70 was cloned by screening the $T$. gondii cDNA library with the human hsp70 probe. Southern blot analysis suggested that the gene is located at a single locus in the $T$. gondii genome. This gene appears to lack an intron between nucleotides $431-2300$, which covers $92.8 \%$ of the coding sequence, suggesting that the $T$. gondii hsp70 gene may be encoded by one continuous open reading frame, similar to the human hsp70 gene (Hunt and Morimoto, 1985). In the $3^{\prime}$ untranslated region, the canonical poly (A) signal AATAAA is not present, although a similar AATAAT sequence is present 10 nucleotides upstream of the poly (A). This signal is also absent in transcripts of other $T$. gondii genes including that of the major surface antigen P30 (Burg et al., 1988).

The overall homology of the deduced amino acid sequence was highest with $P$. falciparum, consistent with their close evolutionary relationship (Kohler et al., 1997). This $T$. gondii hsp70 may be a cytosolic protein because it lacks a signal sequence and ER-retention signal. There were three possible N-glycosylation sites. It is unclear whether these sites are glycosylated, but comparison of the molecular size of the native and recombinant hsp70s (Figs. 4, 5) suggests that there is no extensive glycosylation in these sites. An interesting feature of the deduced amino acid sequence was the presence of multiple repeated sequences; four complete and one incomplete GGMPGGM sequence near the Cterminus. Similar GGMP repeated sequences were observed in all the members of the parasite cytosolic hsp70s that have been cloned to date as well as human and mouse hsc70s. The number of repeats in $T$. gondii hsp70 is particularly high among these proteins and is at a similar level to other protozoan parasites such as $P$. falciparum and T. cruzi. The function of this repeated sequence is unknown but may have a role in adaptation of the parasites to the changing environment during their developmental stages within hosts and vectors.

Western blot analysis of the $T$. gondii lysate with anti-hsp70 mAb, T $\times \mathrm{D} 11$, indicated that $T$. gondii tachyzoites cultured in vitro express this protein. The anti-human hsp70 mAb 1E11 also identified a protein of the same molecular weight. The reciprocal binding of these two mAbs, however, indicated that they are distinct proteins. Although we were unable to detect multiple signals in Southern blot analysis of the $T$. gondii genome with the hsp70 probe under a low stringency condition, the protein identified by $1 \mathrm{E} 11$ is likely a member of the hsp70 family because it can specifically bind to two anti-hsp70 mAbs (1E11 and 7.10) and because of its molecular size. The nature of this protein is unclear and its further understanding may require molecular cloning of the corresponding gene. Lyons and Johnson identified 65- and 70-kDa proteins expressed in $T$. gondii using polyclonal antiserum against the hsp70 of P. falciparum (Lyons and Johnson 1995). The hsp70s identified by our mAbs are clearly distinct from their $70-\mathrm{kDa}$ protein which was expressed in tachyzoites only in vivo and not in vitro. Their $65-\mathrm{kDa}$ protein was similar to the hsp70s identified here in that it is constitutively expressed, although their molecular weights are clearly different. The side by side comparison of the molecular size or the sequential immunoprecipitation with the two Abs will determine whether they are indeed different.

In an attempt to understand the role of $T$. gondiiderived hsp70 in stimulating host immune responses, we investigated the ability of mice infected with $T$. gondii 
to generate humoral immune responses against pathogen-derived hsp70. Two distinct features were observed when compared to the response against soluble tachyzoite antigens. First, the kinetics of the antibody response was quite different. Serum antibody against hsp70 reached peak levels in the acute phase of the infection (1-2 weeks after infection) and then gradually declined. In the chronic phase, the antibody declined to levels barely or not detectable by ELISA or Western blotting. In contrast, the levels of serum antibody against soluble tachyzoite antigen continued to rise during the acute and chronic phases of infection. Several possibilities may account for these kinetic differences. Antibodies to pathogen-derived hsp70 is often cross-reactive to hsp70 of other species including self proteins. The early anti-hsp70 response could be due to the cross-priming of the reactive lymphocytes by hsp70 of other species prior to infection by $T$. gondii. The early clearance of the $\mathrm{Ab}$ may also be explained by the absorption of crossreactive Abs by host-derived hsp70. Alternatively, the kinetic differences might be due to the molecular mechanisms by which hsp70 may be presented to lymphocytes in a manner distinct from other soluble tachyzoite antigens. Proteins of the hsp70 family appear to have unique roles in the induction of immune responses such as carrier effects for its associated molecules (Barrios et al., 1992; Udono and Srivastava, 1993). Finally, T. gondii become encysted bradyzoites with their growth limited in the chronic phase of infection. Our preliminary study suggests that the bradyzoites express hsp70. However, this antigen may become inaccessible to immune recognition leading to failure to maintain the antibody level.

The second difference of the antibody response to T. gondii hsp70 was that only 3 out of a total of 11 infected mice showed significant anti-hsp70 antibody responses in both $\mathrm{BALB} / \mathrm{c}$ and $\mathrm{C} 57 \mathrm{BL} / 6$ mice, while all mice exhibited similar responses against soluble tachyzoite antigens. Age and sex matched mice were used in the experiments, so that it is unlikely to explain these differences. Mice were housed in the same environment and were infected with the same group of cysts. We currently do not know why only some of the infected mice generated significant anti-hsp70 antibody responses. During the course of this study, $5 \mathrm{C} 57 \mathrm{BL} / 6$ mice died between 1 and 2 weeks of infection. Interestingly, all 3 mice that exhibited anti-hsp70 antibody responses survived. However, we did not find any differences in the number of brain cysts between the mice which produced anti-hsp70 antibody during the acute phase of the infection and those that did not.
More detailed study will be required to determine whether there is any correlation between the ability of mice to produce anti-hsp70 antibody and protection against $T$. gondii infection.

The majority of the antibodies produced during acute infection with $T$. gondii appear specific for the $\mathrm{C}$-terminal domain of hsp70, suggesting that the C-terminal peptide binding domain contains the dominant $\mathrm{B}-$ cell epitope. In agreement with this possibility, among our panel of $5 \mathrm{mAbs}$ specific for $T$. gondii hsp70, 4 were specific for the $\mathrm{C}$-terminal and only one was specific for the $\mathrm{N}$-terminal portion of hsp70. Furthermore, antibody responses against $M$. leprae hsp70 were previously shown to be directed mainly to the C-terminal sequences (Davenport et al., 1992). The majority of the antibodies specific for pathogen-derived hsp70 appear directed towards non-conserved sequences of the protein (Engman and Dragon, 1990). However, differences in overall homology in the $\mathrm{C}$ - and $\mathrm{N}$-terminal sequences may not be sufficient to explain the immunodominancy of the C-terminal portion. The homology of the amino acid sequence between mouse and T. gondii hsp70 is $76.7 \%$ in the N-terminus (Ala-2 to Gly-404) and $70.5 \%$ in the C-terminus (Leu-405 to Asp-667). When the GGMP repeated region is excluded, the homology in the $\mathrm{C}$ terminal sequence (Leu-405 to $\mathrm{Gln}-614$ ) is $73.3 \%$. It would be crucial to determine the dominant epitope to understand the molecular basis underlying the immunodominancy of this protein.

Finally, it has been proposed that mammalian hsp70 participates in the processing of peptide antigens within antigen presenting cells (DeNagel and Pierce, 1992; Srivastava, 1993). The members of the hsp70 family of infectious organisms have a conserved structure. They may not only become targets of the immune response but also modulate the presentation of pathogen-derived antigens to specific $T$ cells. With molecular probes now being available, it would be of interest to learn the molecular and cellular mechanisms underlying the stimulation and modulation of the host immune response by a member of the pathogen-derived hsp70s.

\section{ACKNOWLEDGMENTS}

This work was supported in part by Grant-in-Aids for Scientific Research from the Ministry of Education, Science, Sports, and Culture, Japan.

We greatly appreciate for the critical comments and discussions from Drs. K. Yamashita and F. Aosai. We also thank Mr. M. Ueda for his excellent technical help, and Dr. G. Massey for correcting English. 


\section{REFERENCES}

1) Aosai, F., Yang, T.H., Ueda, M. and Yano, A. (1994): Isolation of naturally processed peptides from a Toxoplasma gondii-infected human B lymphoma cell line that are recognized by cytotoxic $\mathrm{T}$ lymphocytes. J. Parasitol., 80, 260-266

2 ) Barrios, C., Lussow, A.R., Van Embden, J., Van der Zee, R., Rappuoli, R., Costantino, P., Louis, J.A., Lambert, P-H. and Del Guidice, G. (1992): Mycobacterial heatshock proteins as carrier molecules. II: The use of the $70-\mathrm{kDa}$ mycobacterial heat-shock protein as carrier for conjugated vaccines can circumvent the need for adjuvants and Bacillus Calmette Guerin priming. Eur. J. Immunol., 22, 1365-1372

3 ) Burg, J.L., Perelman, D., Kasper, L.H., Ware, P.L. and Boothroyd, J.C. (1988): Molecular analysis of the gene encoding the major surface antigen of Toxoplasma gondii. J. Immunol., 141, 3584-3591

4 ) Chappell, T.G., Konforti, B.B., Schmid, S.L. and Rothman, J.E. (1987): The ATPase core of a clathrin uncoating protein. J. Biol. Chem., 262, 76-751

5 ) Chomczynski, P. and Sacchi, N. (1987): Single-step method of RNA isolation by acid guanidium thiocyanate-phenol-chloroform extraction. Anal. Biochem., 162, 156-159

6 ) Davenport, M.P., McKenzie, K.R., Basten, A. and Britton, W.J. (1992): The variable C-terminal region of the Mycobacterium leprae 70-kilodalton heat shock protein is the target for humoral immune responses. Infect. Immun., 60, 1170-1177

7 ) DeNagel, D.C. and Pierce, S.K. (1992): A case for chaperones in antigen processing. Immunol. Today, 13, 86-89

8 ) Dworniczak, B. and Mirault, M.-E. (1987): Structure and expression of a human gene coding for a $71 \mathrm{kd}$ heat schock 'cognate' protein. Nucleic Acid Res., 15, 51815197

9 ) Engman, D.M., Dragon, E.A. and Donelson, J.E. (1990): Human humoral immunity to hsp70 during Trypanosoma cruzi infection. J. Immunol., 144, 3987-3991

10) Freeman, B.C., Myers, M.P., Schumacher, R. and Morimoto, R.I. (1995): Identification of a regulatory motif in Hsp70 that affects ATPase activity, substrate binding and interaction with HDJ-1. EMBO J., 14, 2281-2292

11) Frenkel, J.K. (1988) Pathophysiology of toxoplasmosis. Parasitol. Today, 4, 273-278

12) Gething, M.-J. and Sambrook, J. (1992): Protein folding in the cell. Nature, $355,33-45$

13) Giebel, L.B., Dworniczak, B.P. and Bautz, E.K.F. (1988): Developmental regulation of a constitutively expressed mouse mRNA encoding a $72-\mathrm{kDa}$ heat shock-like protein. Dev. Biol., 125, 200-207

14) Hartl, F.U. (1996): Molecular chaperones in cellular protein folding. Nature, 381, 571-580

15) Hedstrom, R., Culpepper, J., Harrison, R.A., Agabian, N. and Newport, G. (1987): A major immunogen in Schis- tosoma mansoni infections is homologous to the heatschock protein Hsp70. J. Exp. Med., 165, 1430-1435

16) Hombeck, P., Enzyme-linked immunoadsorbent assays, in Current Protocols in Immunology, J.E. Coligan, et al., Editor. (1996): John Wiley \& Sons: New York. p. 2.1. 2-2.1.22

17) Hunt, C. and Morimoto, R.I. (1985): Conserved features of eukaryotic hsp70 genes revealed by comparison with the nucleotide sequence of human hsp70. Proc. Natl. Acad. Sci. USA, 82, 6455-6459

18) Kohler, S., Delwiche, C.F., Denny, P.W., Tilney, L.G., Webster, P., Wilson, R.J.M., Palmer, J.D. and Roos, D.S. (1997): A plastid of probable green algal origin in apicomplexan parasites. Science, 275, 1485-1489

19) Komori, S., Katsumata, M., Greene, M.I. and Yui, K. (1993): Frequent deletion of the transgene in $\mathrm{T}$ cell receptor $\beta$ chain transgenic mice. Int. Immunol., $5,161^{-}$ 167

20) Kurtz, S., Rossi, J., Petko, L. and Lindquist, S. (1986): An ancient developmental induction: heat shock proteins induced in sporulation and oogenesis. Science, 231, 1154

21) Lyons, R.E. and Johnson, A.M. (1995): Heat shock proteins of Toxoplasma gondii. Parasite Immunology, 17, 353-9

22) MacFarlane, J., Blaxter, M.L., Bishop, R.P., Miles, M.A. and Kelly, J.M. (1990): Identification and characterization of a Leishmania donovani antigen belonging to the $70-\mathrm{kDa}$ heat-shock protein family. Eur. J. Biochem., 190, 377-384

23) McCabe, R. and Remington, J.S. (1988): Toxoplasmosis: the time has come. N. Engl. J. Med., 380, 313

24) McKenzie, K.R., Adams, E., Britton, W.J., Garsia, R.J. and Basten, A. (1991): Sequence and immunogenicity of the $70-\mathrm{kDa}$ heat shock protein of Mycobacterium leprae. J. Immunol., 147, 312-319

25) Melnick, J. and Argon, Y. (1995): Molecular chaperones and the biosynthesis of antigen receptors. Immunol. Today, 16, 243-250

26) Srivastava, P.K. (1993): Peptide-binding heat shock proteins in the endoplasmic reticulum: role in immune response to cancer and in antigen presentation. Adv. Cancer Res., 62, 153-177

27) Tamura, A. and Yui, K. (1995): Age-dependent reduction of Bcl-2 expression in peripheral T cells of $l p r$ and gld mutant mice. J. Immunol., 155, 499-507

28) Udono, H. and Srivastava, P.K. (1993): Heat shock protein 70-associated peptides elicit specific cancer immunity. J. Exp. Med., 178, 1391-1396

29) Yang, T.-H., Aosai, F., Norose, K., Ueda, M. and Yano, A. (1995): Enhanced cytotoxicity of IFN- $\gamma$-producing $\mathrm{CD} 4{ }^{+}$cytotoxic $\mathrm{T}$ lymphocytes specific for $T$. gondii infected human melanoma cells. J. Immunol., 154, 290298

30) Yang, Y.-F., Tan-Ariya, P., Sharma, Y.D. and Kilejian, A. (1987): The primary structure of a Plasmodium falciparum polypeptide related to heat shock proteins. 
Mol. Biochem. Parastol., 26, 61-68

31) Yano, A., Aosai, F., Ohta, M., Hasekura, H., Sugane, K. and Hayashi, S. (1989): Antigen presentation by Toxoplasma gondii-infected cells to $\mathrm{CD}^{+}$proliferative $\mathrm{T}$ cells and $\mathrm{CD} 8^{+}$cytotoxic T cells. J. Parasitol., 75, 411416

32) Young, R.A., Mehara, V., Sweester, D., Buchanan, T.,
Clark-Curtiss, J., Davis, R.W. and Bloom, B.R. (1985): Genes for the major protein antigens of the leprosy parasite Mycobacterium leprae. Nature (Lond.), 316, 450 33) Yui, K., Hashimoto, Y. and Greene, M.I. (1988): T cell receptors of autoimmune mice: Functional and molecular analysis of novel $\mathrm{T}$ cell subsets in $\mathrm{C} 3 \mathrm{H}-$ gld/gld mice. Immunol. Res., 7, 173-188 